This is an informal report intended primarily for internal or

UCID - 16316 limited external distribution. (The opinions and conclusions stated are those of the author and may or may not be those of the laboratory.) Thisreport is no be given-additionaloxternot -distribution or eited in externat doeuments without the consent. of the auther or ILL Technical Information-Departments.

\author{
㢟 \\ LAWRENCE LIVERMORE LABORATORY \\ University of California/Livermore, California

\section{A PLANT OPERATING SCHEDULE AND PRODUCTION RATE \\ FOR NUCLEAR CHEMICAL MINING OF COPPER}

by

R. Mallon and J. Cramer

July 24,1973

NOTICE

This report was prepared as an account of work sponsored by the United States Government, Neither the United States nor the United States Atomic Energy Commission, nor any of their employees, nor any of Commission, nor any of their employees, nor any of their contractors, subcontractors, or their employees, makes any warranty, express or implied, or assumes any pleteness or usefulness of any information, apparatus, product or process disclused, or represents that its use would not infringe privately owned rights. 


\section{DISCLAIMER}

This report was prepared as an account of work sponsored by an agency of the United States Government. Neither the United States Government nor any agency Thereof, nor any of their employees, makes any warranty, express or implied, or assumes any legal liability or responsibility for the accuracy, completeness, or usefulness of any information, apparatus, product, or process disclosed, or represents that its use would not infringe privately owned rights. Reference herein to any specific commercial product, process, or service by trade name, trademark, manufacturer, or otherwise does not necessarily constitute or imply its endorsement, recommendation, or favoring by the United States Government or any agency thereof. The views and opinions of authors expressed herein do not necessarily state or reflect those of the United States Government or any agency thereof. 


\section{DISCLAIMER}

Portions of this document may be illegible in electronic image products. Images are produced from the best available original document. 


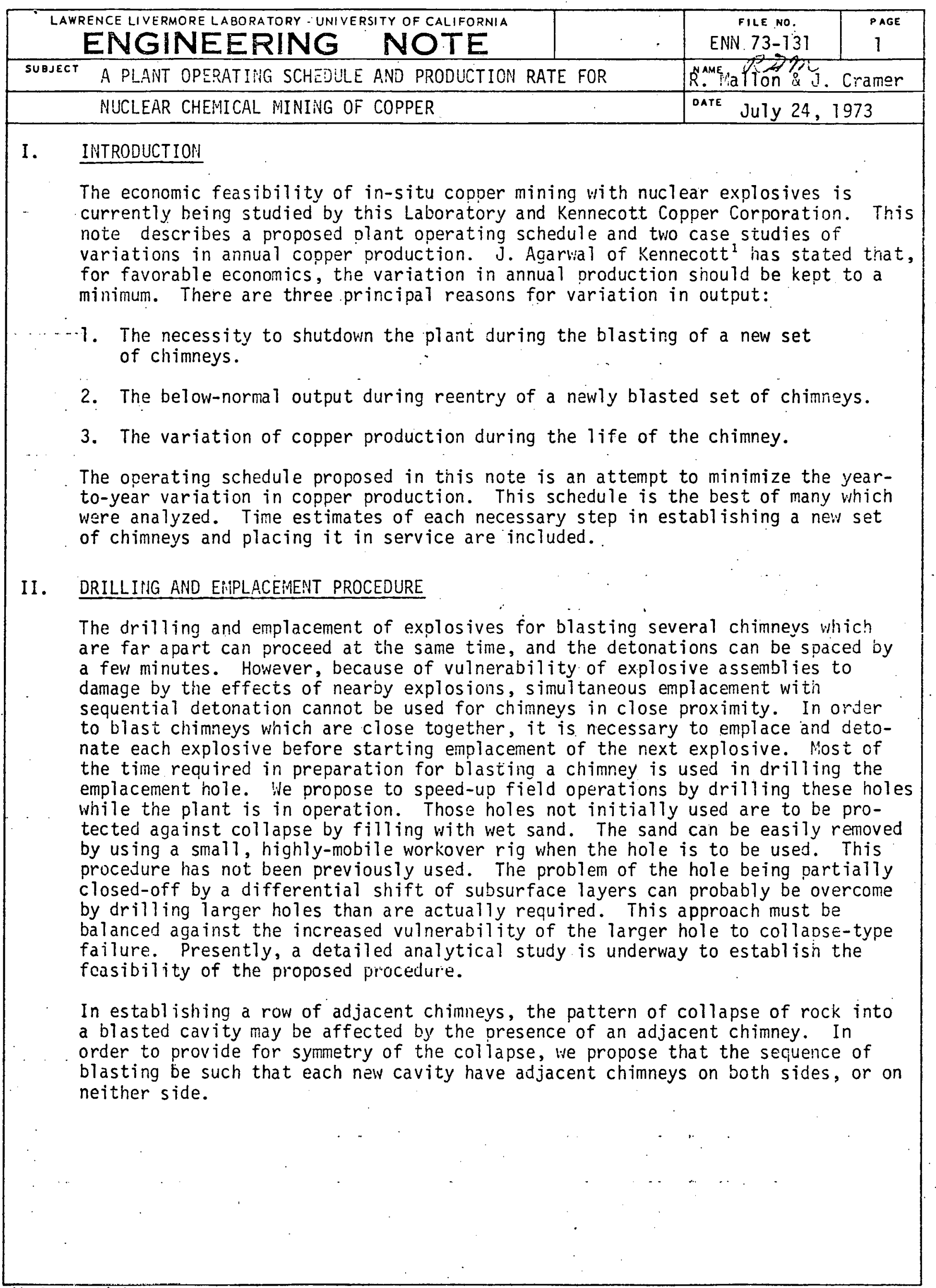




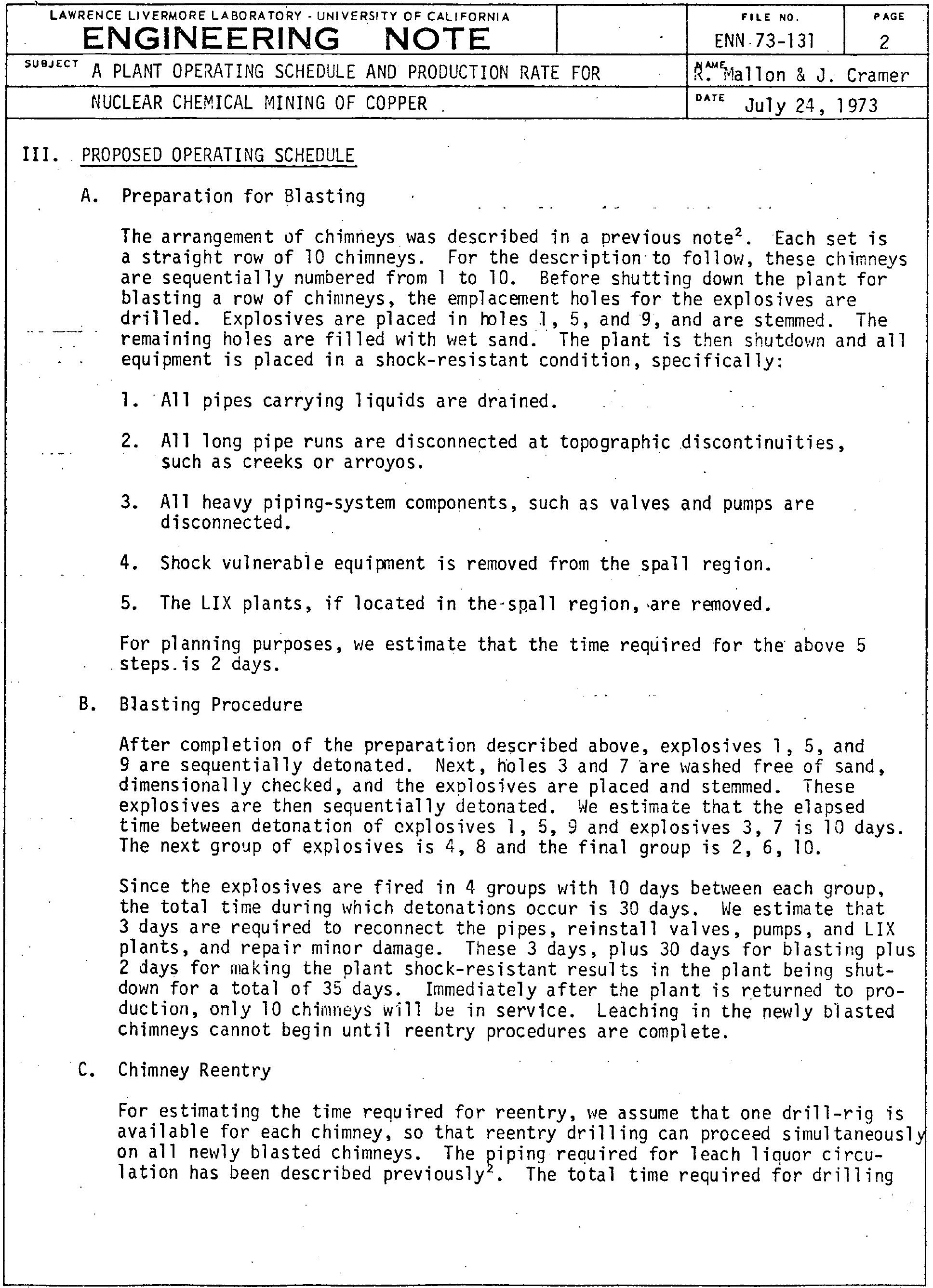


SUBJECT A PLANT OPERATING SCHEDULE AND PRODUCTION RATE FOR k.Mamiallon \& J. Cramer.

and setting pipe for all the required flow lines is estimated to be 130 days. In addition, we allow an average of 5 days for late arrival of the drill-rigs used for reentry. Thus, we estimate that leaching of new chimneys will begin 135 days after the final detonation.

\section{COMPUTATION OF OUTPUT}

The computation of annual copper production is performed for two different rates of flow of leach liquor to the LIX olant. For the first case, the flow from each chimney is held constant at $540 \mathrm{gpm}$ throughout the life of the chimney and the LIX processing is started at the same time that leaching is started. These assumptions and all other parameters used in the calculation are the same as those used previousiy ${ }^{2}$. Figure 1 shows the variation of copper concentration in the leach liquor in a chimney. If separate LIX plants are provided for each chimney, the concentration shown on Figure 1 is the concentration in the LIX feed. If a LIX plant receives flow from several chimneys of different ages, the LIX plant feed concentration will be the weighted average of the concentrations in the chimneys from which the LIX plant is supplied. The copper production rate per chimney is derived from the curve on Figure 1. The copper produced from a chimney during a selected time interval is obtained by multiplying the flow rate to LIN by the area under the curve during that time interval. The copper produced by 10 chimneys of the same age during each of the 6 leaching years is shown below.

\section{Chimney Production - Constant Flow To LIX}

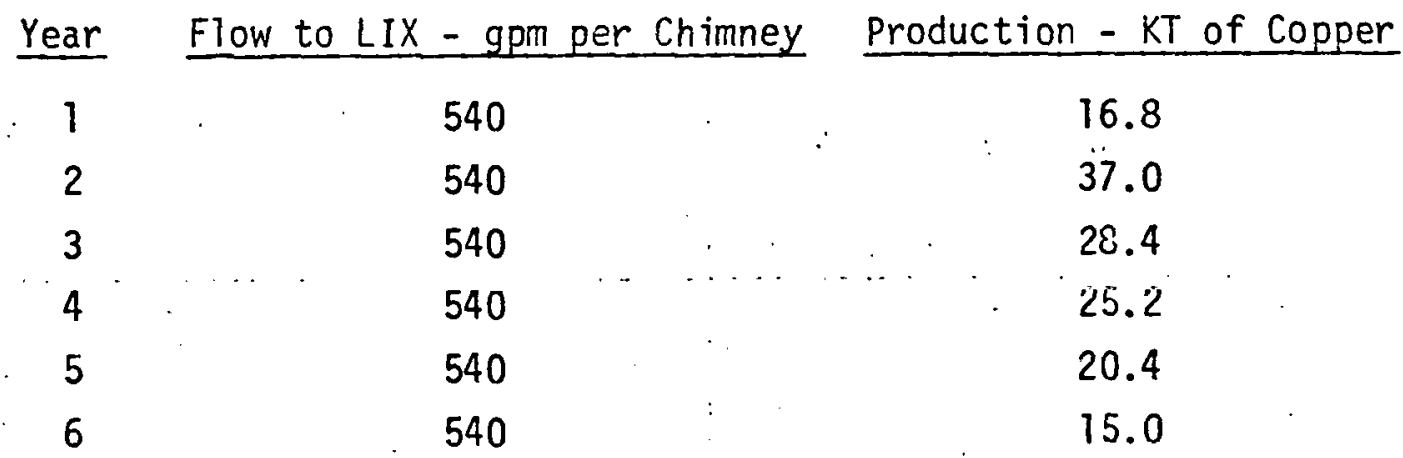

For this computation, the first year starts on the day of the last detonation. During the first year, the first 135 days are lost from leaching operation of the new chimneys because of reentry operations. During the third year, the last 32 days are lost because of silutdown operations and blasting of the next row of chimneys. Since year one for each row of chimneys was defined to start on the day of the last detonation, the first 3 days of the fourth year are lost for plant restart operations. Finally, during the sixth year, 32 days are aga in lost during plant shutdown and blasting. The total number of days during which leaching is in progress in each chimney is 1988.

Figure 2 shows a chart of the plant-operations schedule. The operation of each row of chimneys is indicated. Each year's copper production is also shown. It is seen that the annual production varies with a 3 year cycle after full production is reached. The minimum of this cycle is 42.0 kilotons per year, and the 


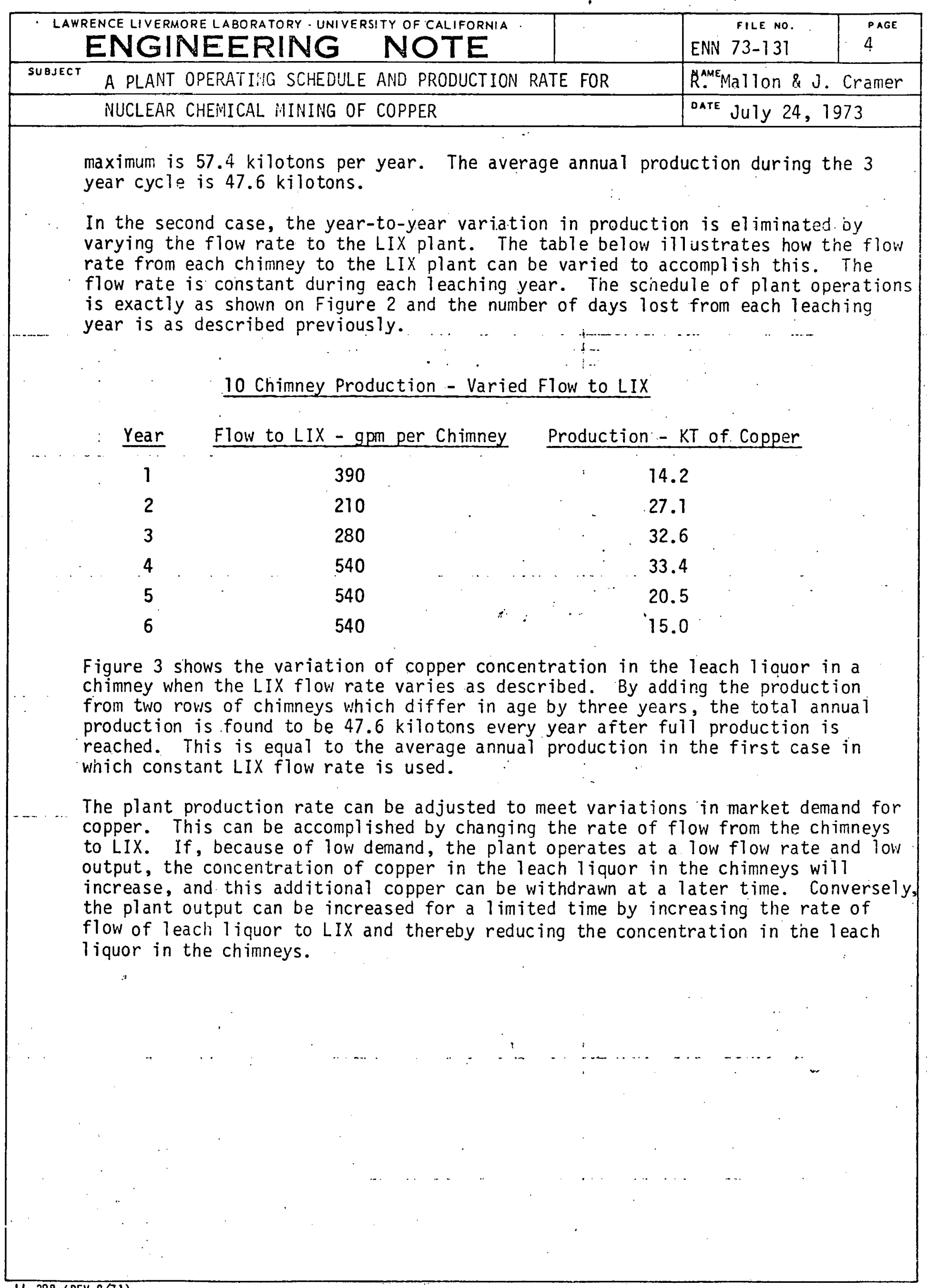




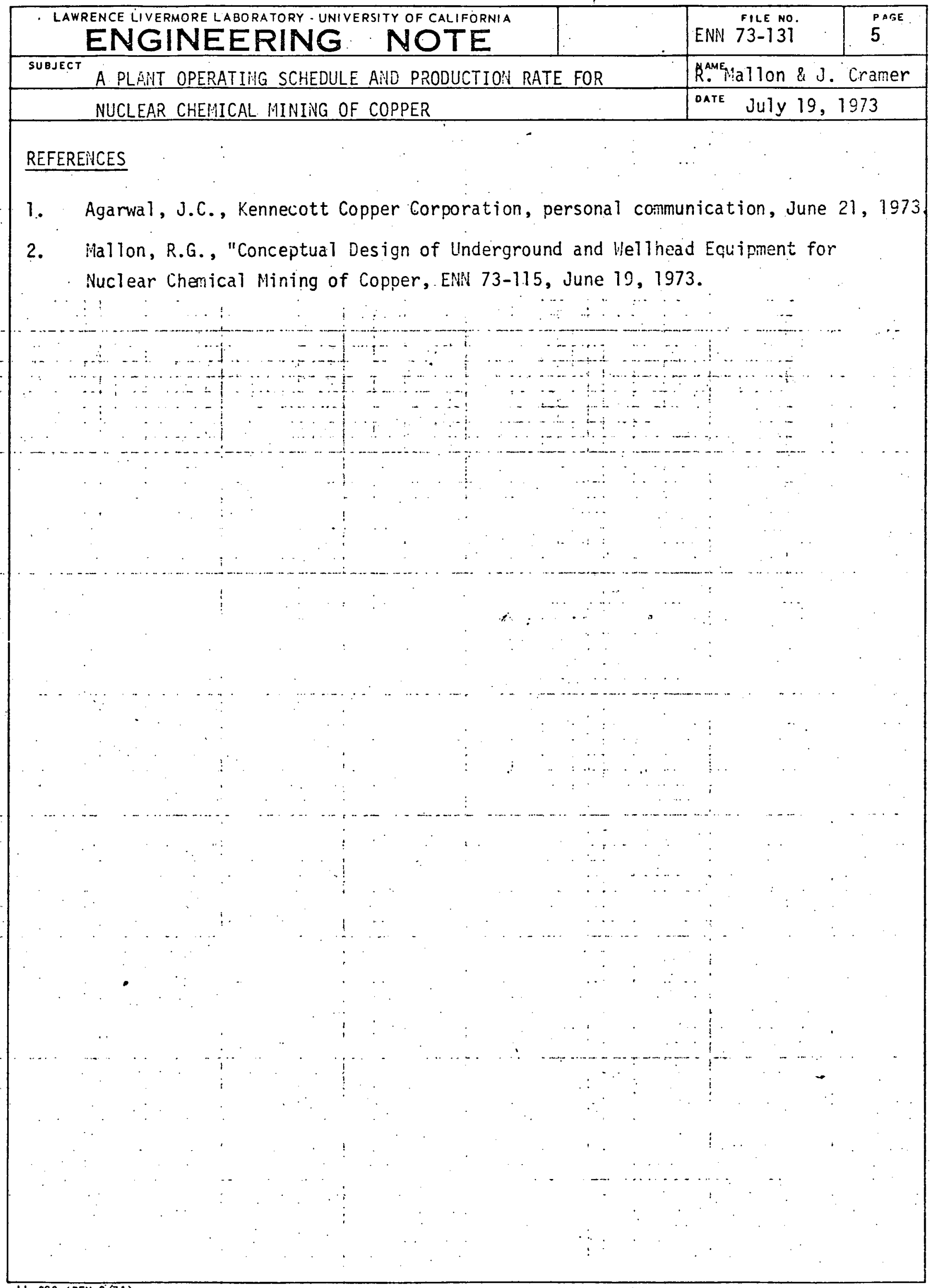




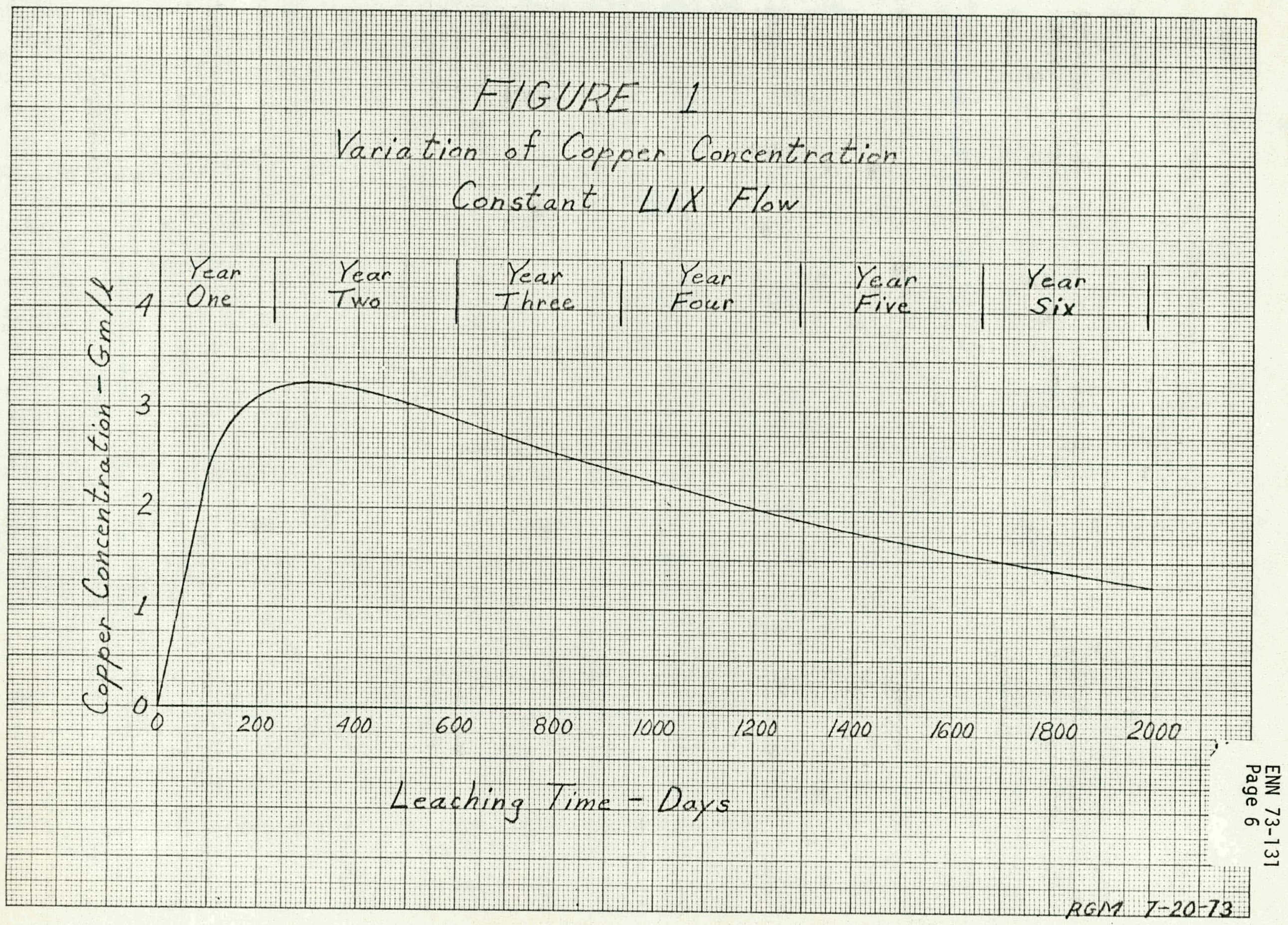




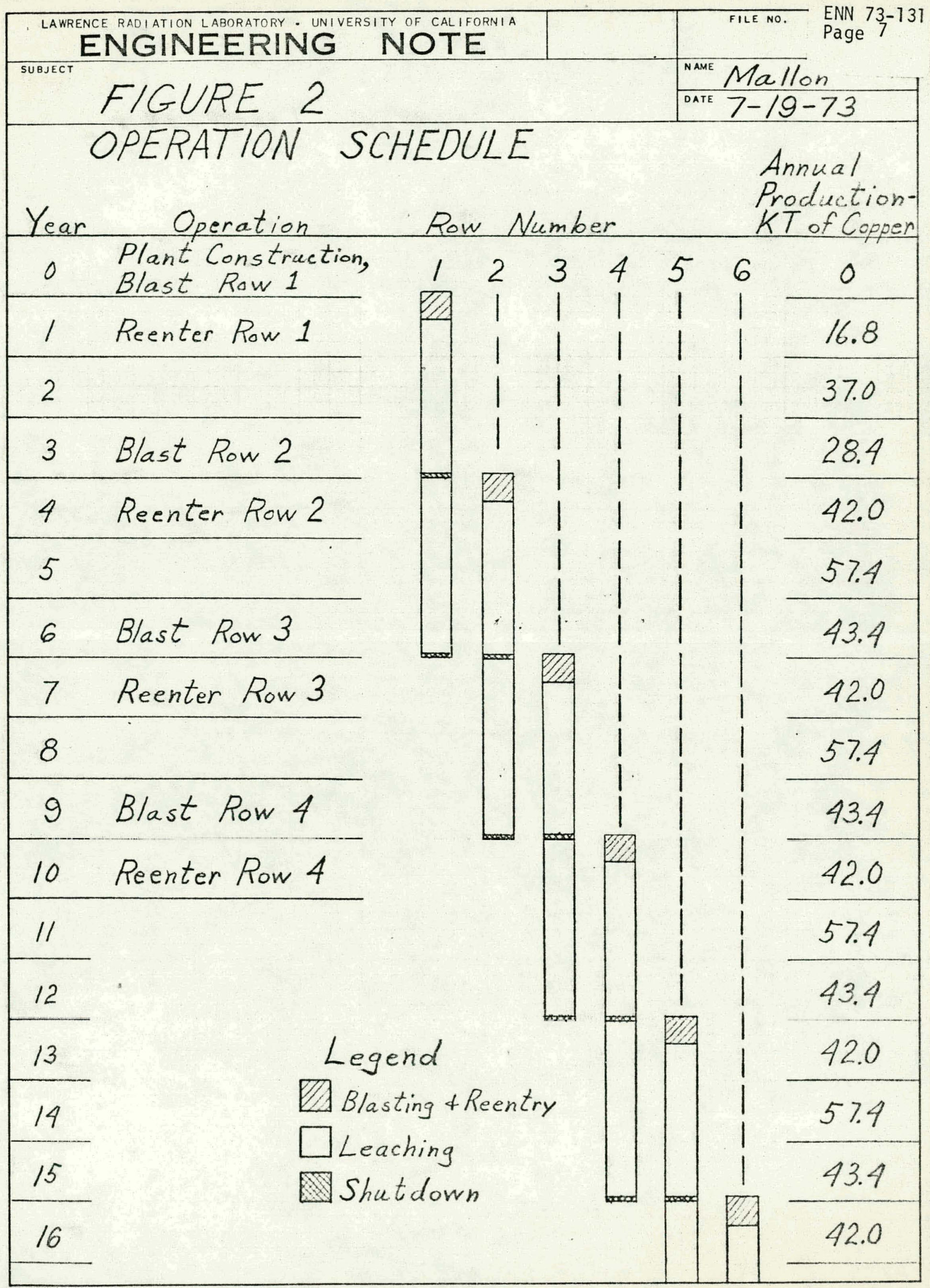




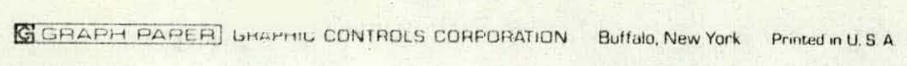

SQUare $10 \times 10$ TO The CENTIMEter AS-8014-6T

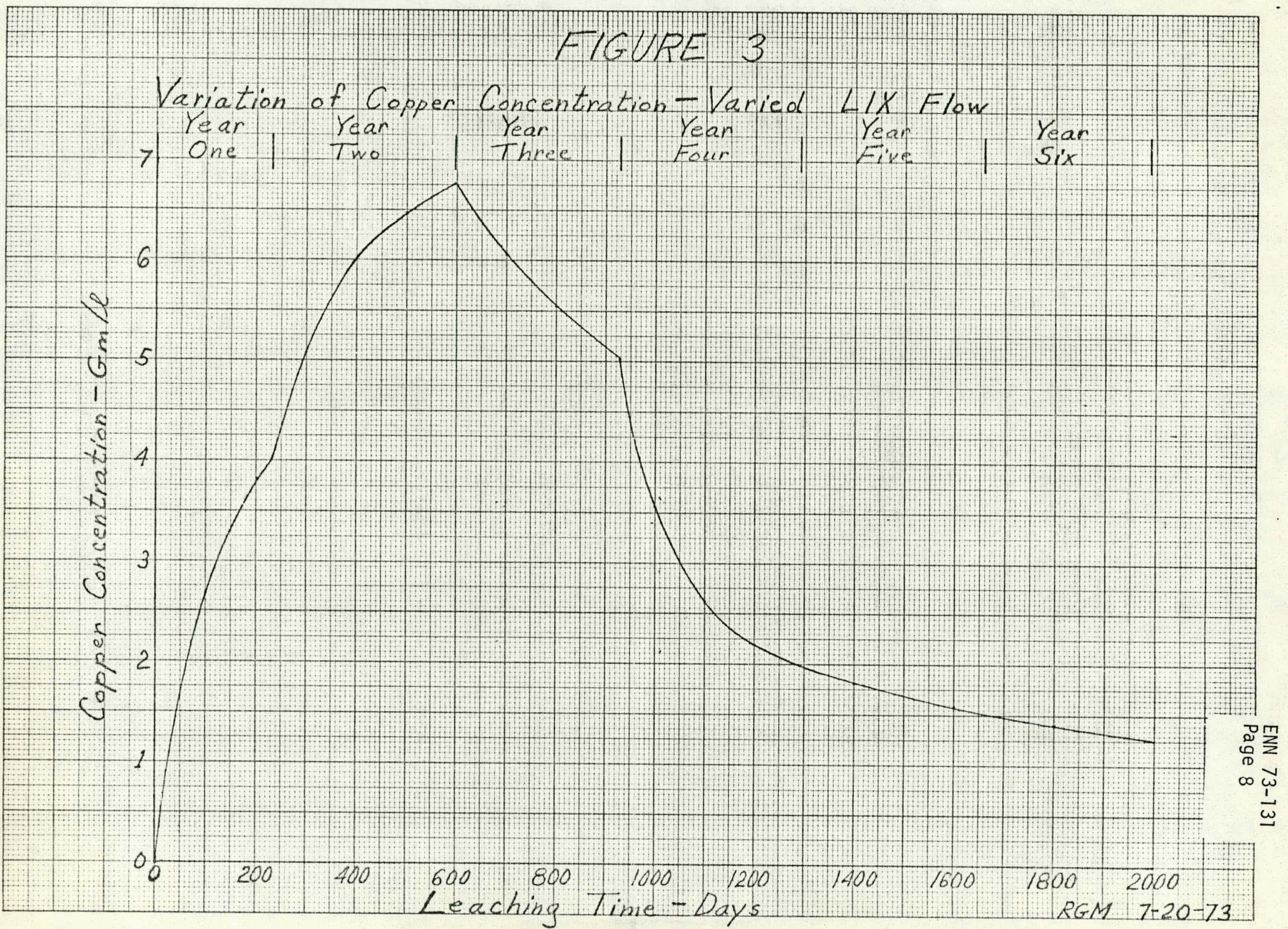




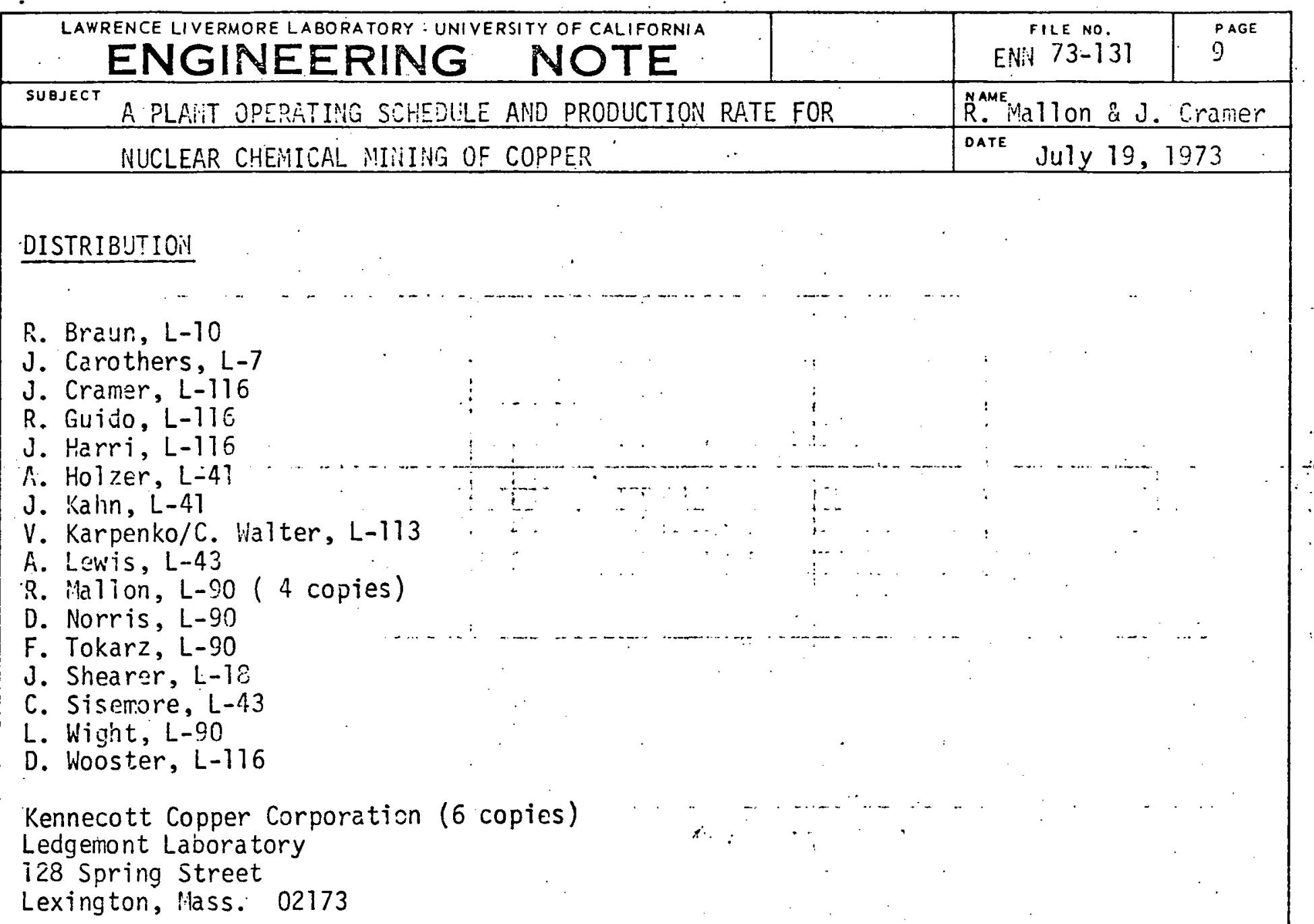

Attention: Mr. Jagdish C. Agarwal 